\title{
Risk factors for measles outbreak in Ataq and Habban districts, Shabwah governorate, Yemen, February to May 2018
}

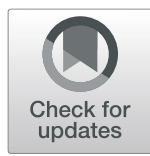

Abdulkareem Ali Hussein Nassar ${ }^{1 *}$ (D) Mohammed Abdullah Al Amad² (D, Mohammed Qasim ${ }^{3}$ (D) and Fekri Dureab ${ }^{4,5}$ (D)

\begin{abstract}
Background: Recent conflict and war in Yemen lead to collapse of the health system, decrease of immunization coverage and spread of many outbreaks. On May 22, 2018, the surveillance officer in Shabwah governorate reported an increased number of suspected measles. On May 24, 2018, a team from Yemen-Field Epidemiology Training Program was sent to investigate. The aims were to describe the outbreak, determine the risk factors for measles infection and recommend control measures.

Methodology: A descriptive followed by case-control study design (1:2 ratio) were performed. National Measles Surveillance Program case definition and predesigned questionnaire were used to collect data from 73 cases and 146 controls. Attack rate (AR), adjusted odds ratios (aOR) and $95 \%$ confidence intervals $(95 \% \mathrm{Cl})$ were calculated. $P$ value $<0.05$ was considered as the cut point for significant. Epi info version 7.2 was used.

Results: A total of 73 suspected cases were found. Almost 53\% were from Habban district, $63 \%$ were males and $56 \%$ were among age group $<5$ years. The overall AR was $82 / 100,000$ population. Measles was significantly associated with contact with case $(\mathrm{aOR}=27.3,95 \% \mathrm{Cl}: 1.3-551.7)$, malnourished children aged 6-60 months (aOR $=$ 24.9, 95\% Cl;1.9-329.6) and unvaccinated children ( $\mathrm{aOR}=17.2,95 \% \mathrm{Cl}: 2.9-100.7)$. The six collected blood samples found to be positive for measles IgM.

Conclusions: Measles outbreak in Ataq and Habban districts was confirmed. Contact with measles cases, malnutrition and un-vaccination were the potential contributing factors of measles outbreak in Shabwah governorate. An urgent vaccination campaign with health education interventions are highly recommended. Reactivation of the outreach immunization services and strengthening surveillance and response systems are top priority to take place at district and governorate levels.
\end{abstract}

Keywords: Measles outbreak, Risk factors, Shabwah governorate, Yemen

\footnotetext{
*Correspondence: abdulkareemnassar@gmail.com

'Sana'a City's Public Health and Population Office, Yemen Ministry of Public Health and Population, Sana'a, Yemen

Full list of author information is available at the end of the article
}

(c) The Author(s). 2021 Open Access This article is licensed under a Creative Commons Attribution 4.0 International License, which permits use, sharing, adaptation, distribution and reproduction in any medium or format, as long as you give appropriate credit to the original author(s) and the source, provide a link to the Creative Commons licence, and indicate if changes were made. The images or other third party material in this article are included in the article's Creative Commons licence, unless indicated otherwise in a credit line to the material. If material is not included in the article's Creative Commons licence and your intended use is not permitted by statutory regulation or exceeds the permitted use, you will need to obtain permission directly from the copyright holder. To view a copy of this licence, visit http://creativecommons.org/licenses/by/4.0/. The Creative Commons Public Domain Dedication waiver (http://creativecommons.org/publicdomain/zero/1.0/) applies to the data made available in this article, unless otherwise stated in a credit line to the data. 


\section{Background}

Measles is a highly infectious human diseases caused by the measles virus that belongs to the family Paramyxoviridae and frequently results in widespread outbreaks $[1,2]$. It is often characterized by high morbidity and mortality rates globally, particularly in African and other developing countries. Mortality from measles infection is often secondary to severe complications [3]. Complications of measles include severe pneumonia, diarrhea, blindness, deafness and encephalitis [1, 3].

Globally; in 1980, before widespread vaccination, measles caused more than two million deaths each year [4]. As a result of the global effort to eradicate the measles virus by vaccination, approximately 20 million measles deaths have been saved. Using an effective vaccine reduced the deaths number from 550,000 to 90,000 during 2000 to 2016 [1, 5], the majority from developing countries, which accounted for $5 \%$ of all under-five mortality [1]. However, measles is still one of leading causes of death among children globally [4].

Despite the number of measles cases reduced in The East Mediterranean Region (EMR) in the latest years, it's still a problem in the region. The number of reported suspected measles were 34,835 in 2015 and 28,225 in 2016 while the laboratory confirmed measles were 8853 in 2015 and 5201 cases in 2016. In 2016, measles incidence per 1000,000 populations was higher in Sudan (42.94), followed by Oman (34.66) and United Arab Emirates (23.92) [6].

Collapse of the health system due to the ongoing war in Yemen lead to low vaccination coverage [7], that reported by $64 \%$ during 2017 in all Yemeni governorates [8]. The reported measles cases from January to May 2018, a total of 4474 measles and 91 deaths were reported compared with 3529 measles and 8 deaths were reported through 2017 [9, 10]. Many outbreaks were investigated in some governorates. Such as Hajjah governorate in 2012 [11] and Al Hudaydah governorate in 2014 [12], Al Jawf and Sa'adah governorates in March 2015 [13, 14], and Amran governorate in 2017 [15]. The measles outbreaks still have occurred in 2018. Yemen remains under threat of measles epidemic due to collapse of the health system and continuing of the war.

On May 22, 2018, Shabwah governorate surveillance officer notified the Ministry of Health about an increased number of measles cases in the governorate. On May 24, 2018, Yemen Field Epidemiology Training Program sent a team to perform an investigation. Moreover, studying the risk factors will provide a valuable information to be used for better understanding and control the measles outbreak. The study aims to confirm the existence of measles outbreak in Ataq and Habban districts, describe the characteristics of measles outbreak by person, place and time, determine the risk factors of measles outbreak, and recommend the appropriate control and prevention measures.

\section{Methodology \\ Study design and area}

A descriptive followed by case-control study design was conducted in Ataq and Habban districts, Shabwah governorate, Yemen. Shabwah is located in the southeastern part of Yemen, along the Arabian Sea coast. It is $474 \mathrm{~km}$ southeast of the capital city of Sana'a. It has 632,000 populations distributed in 17 districts [16].

Based on electronic Integrated Disease Early Warning System data, Ataq and Habban districts were the most affected districts in the governorate $[9,17]$. Descriptive part of this study was conducted to describe the characteristics of measles outbreak by person, place and time, while a case-control part was conducted to identify the risk factors associated with measles outbreak.

\section{Sample size}

A sample size of 219 with ratio 1:2 (73 cases and 146 control) were included from Ataq and Habban districts. As a result of security reasons, and the limited resources and period for investigation, an obtainable and convenience sample size was determined as 55\% of 132 reported measles cases in Ataq and Habban districts.

\section{Selection of cases and controls}

The National Measles Surveillance Program case definition (any person who lived in Ataq or Habban district, suffered from fever and skin rash since February 2018) was used to identify the cases.

Control defined as: any person who lived in Ataq or Habban district, did not suffer from fever nor skin rash since February 2018. The sex of controls units was matched with the cases.

\section{Data and laboratory sample collection}

Active search from house to house was performed. A predesigned questionnaire was adopted from literatures [18-22]. The questionnaire was used to collect data related to the following variables: sociodemographic, onset date, clinical symptoms, vaccination status (based on vaccination cards or parents recall), contact with suspected case and presence of suspected case in the same area. Also it included questions related to parents' education level, nutritional status for children aged 6-60 months (mid-upper-arm circumference) [23], house ventilation, distance between home and health facility, and number of family members and rooms. Six blood samples were collected and sent to the National Center for Public Health laboratory to be tested by ELISA. 


\section{Data processing and analysis}

Data was cleaned and entered into Excel program and then analyzed by Epi info version 7.2. The distance between home and health facility, and crowding (number of persons per room) were categorized by mean. Nutritional status of children aged 6-60 months were categorized according to the cut-off point of mid-upper arm circumference at $115 \mathrm{~mm}:<115 \mathrm{~mm}$ as malnutrition and $\geq 115 \mathrm{~mm}$ as normal [23]. Family size categorized by average household size in Yemen into $<7$ or $\geq 7$ persons [24]. Vaccination status were categorized into unvaccinated (those who have never received a vaccine dose) and vaccinated (those who have received at least one dose of measles vaccine). The Attack Rate (AR) was calculated as the total number of measles cases divided by the total population and expressed per 100,000. Univariate and multivariate binary logistic regression were used to calculate the crude Odds Ratio (cOR) and the adjusted Odds Ratio (aOR) with 95\% Confidence Interval (CI). Each variable that has $P$ value $\leq 0.25$ was entered into multivariate analysis. P value $<0.05$ was considered as the cut point for statistically significant in multivariate analysis.

\section{Results}

A total of 73 measles cases were found in both Ataq and Habban districts. The first case was in Epidemiological week number 7 . There were two peaks during the course period of the outbreak; the first peak was in epidemiological week number 15 and the second peak was the highest peak occurred in epidemiological week 21 (Fig. 1).

Table 1 shows that $56 \%$ of cases were among the children under-5 years old and $62 \%$ were males. About $53 \%$ of cases were from Habban district and 47\% from Ataq district. The overall AR was $82 / 100,000$ of population. The AR was higher among the children under- 5 years old (288 vs 43 / 100,000). Similarly, the AR was higher among males than females (94 vs 68/100,000) and in Habban than Ataq district (98 vs 69/100,000).

Figure 2 shows that all cases suffered from fever and skin rash, and 93\% were suffered from cough, conjunctivitis and runny nose. However only $25 \%$ of the patients had lymph node enlargement. Only six blood samples were collected randomly from the patients and all were positive for measles IgM.

Table 2 shows the distribution of potential risk factors for measles by study group, the children under- 5 years old, illiterate or basic education level of parents, malnourished children, unvaccinated children, and previous contact with measles cases were significantly associated with being a case. The findings show the non-adjusted and adjusted findings from the logistic regression analysis of factors associated with measles cases. In the univariate analysis, the children under-5 years old were 2 times more likely to be cases ( $\mathrm{cOR}=2.4,95 \%$ CI:1.34.2 ), while those who had parents with basic education or totally illiterate were more likely to be a case of measles among fathers ( $\mathrm{cOR}=2.2,95 \% \mathrm{CI}: 1.2-3.9)$ less likely than mothers $(\mathrm{cOR}=4.7,95 \% \mathrm{CI}: 1.1-20.8)$. Moreover, cases were found more likely among malnourished children aged 6-60 months ( $\mathrm{cOR}=4.8,95 \% \mathrm{CI} ; 1.2-18.7$ ), unvaccinated children ( $\mathrm{cOR}=19.9,95 \% \mathrm{CI}$ : 9.3-43.1), contacted with measles case (cOR $=37.3,95 \% \mathrm{CI}$ : 14.0 99.2) and the presence of measles case in the same area $(\mathrm{COR}=17.9,95 \% \mathrm{CI}: 8.5-37.7)$. As well as bad ventilated houses $(\mathrm{cOR}=5.5,95 \% \mathrm{CI}: 2.9-10.5)$ and living in crowded rooms (cOR $=1.8,95 \% \mathrm{CI}: 1.0-3.2)$.

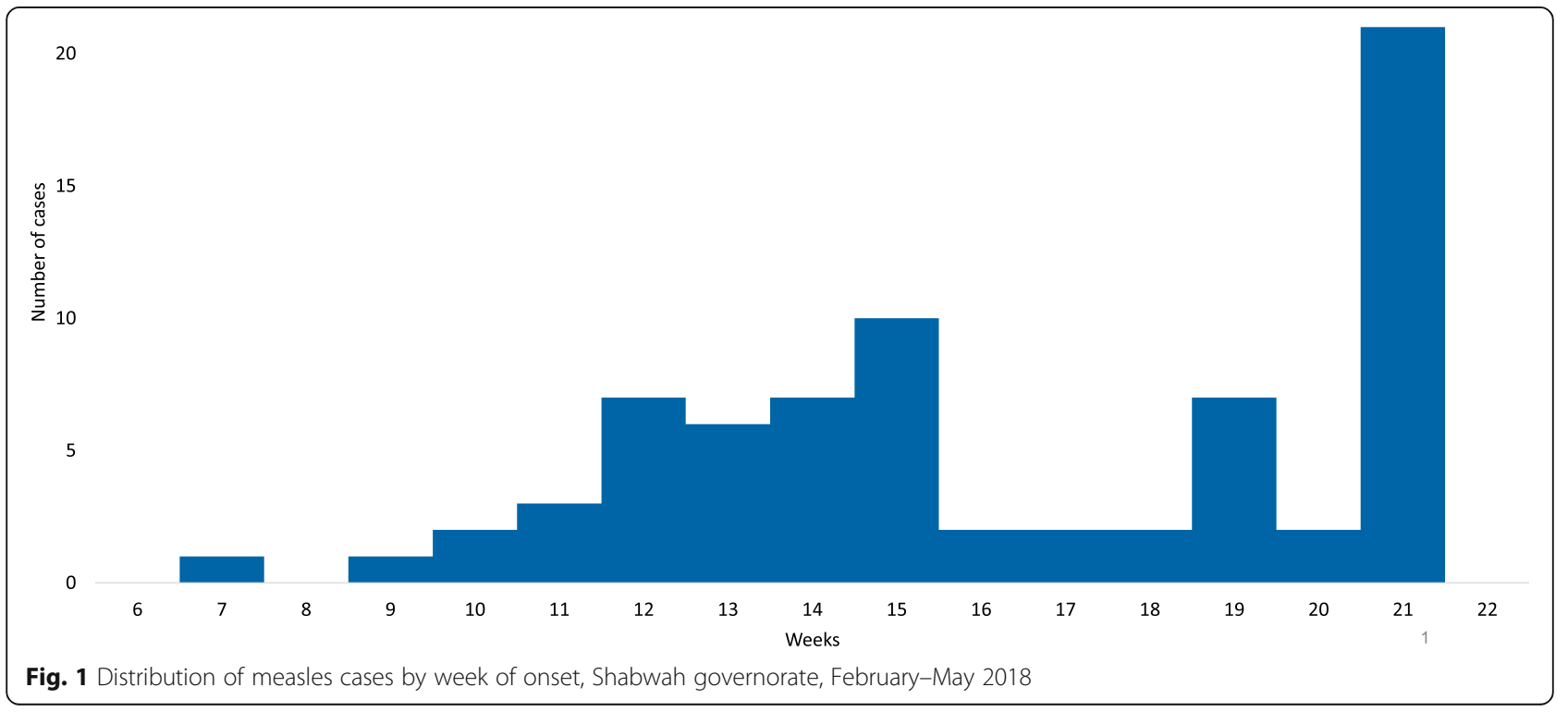


Table 1 Age, sex and district specific attack rates of measles cases, Shabwah governorate, February-May 2018

\begin{tabular}{llll}
\hline Variables & Population & $\begin{array}{l}\text { Cases } \\
\text { No. (\%) }\end{array}$ & Attack rate (per 100,000) \\
\hline $\begin{array}{lll}\text { Age group (years) } \\
<5\end{array}$ & 14,247 & $41(56)$ & 288 \\
$\geq 5$ & 75,034 & $32(44)$ & 43 \\
Sex & & & \\
Male & 47,859 & $45(62)$ & 94 \\
Female & 41,422 & $28(38)$ & 68 \\
Districts & & & \\
Habban & 39,709 & $39(53)$ & 98 \\
Ataq & 49,572 & $34(47)$ & 69 \\
Total & 89,281 & $73(100)$ & 82 \\
\hline
\end{tabular}

In multivariate analysis, malnourished children aged 6-60 months $(\mathrm{aOR}=24.9$, 95\% CI:1.9-329.6), unvaccinated children ( $\mathrm{aOR}=17.2$, 95\% CI:2.9-100.7) and contacted patient with measles $(\mathrm{aOR}=27.3$, 95\% CI:1.3551.7) remained significantly associated risk factors with being a measles case.

\section{Discussion}

Measles outbreaks exacerbated in Yemen as a result of ongoing war that lead to the collapse of the health system in all levels.

The result of this investigation revealed the highest peak of cases in week 21, this might be due to the aggregation of cases as a result of our investigation that was performed around this week. This indicated that the outbreak is still continuing in the affected area. Our finding shows that males were more affected than females. Our finding is consistent with previous investigations in $\mathrm{Al}$ Jawf and Sa'adah governorates [13, 18], and inconsistent with others in Amran governorate [15] and Ethiopia [19]. This is may be due to the fact that males are more mobile or socially active than females. Age group < 5 years was more affected; as a result of the war that led to collapse in the health system including lowering immunization coverage and the accumulation of the susceptible population in the age group $<5$ years. This result is similar to studies in Al Jawf, Sa'adah, Amran governorates $[13,14,16]$ and two in Ethiopia and Nepal $[19,25]$. The higher AR is most likely due to the high susceptibility of population. Moreover, the overall AR in Habban was more than Ataq districts due to the unvaccination status which was higher in Habban than Ataq districts. Furthermore, the immunization coverage in Habban (61 and 27\%) is lower than Ataq district (93 and 66\%) in 2017 and 2018, respectively [26]. Similar findings were found in several studies in Qufl Shamr district, Hajjah governorate and in Ethiopia [13, 27].

The result of the case control study shows the factors that related to spreading of measles infections among the population. Our investigation indicated that there isn't a significant association between the children under-5 years and measles infection. This result is consistent with two studies in Ethiopia [28, 29]. Similarly, the children of illiterate or low educated fathers were found to be not significantly associated factor for measles infection. Our result agrees with study in Indonesia [30] and disagrees with study in Iran [22]. Moreover, the

Lymph node enlargment

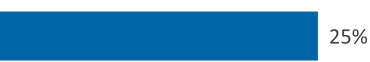

Runny nose

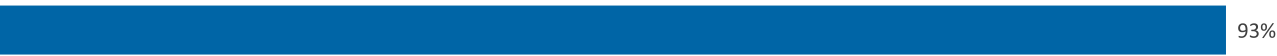

Conjunctivitis

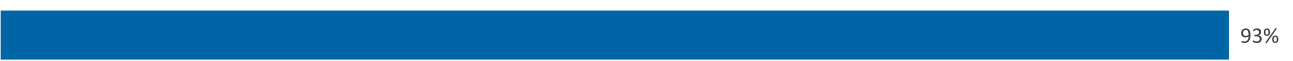

$$
\text { Cough }
$$

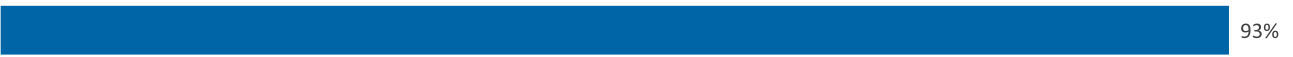

Fever

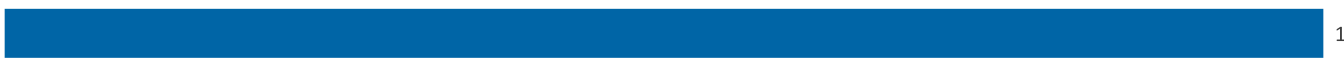

Skin rash

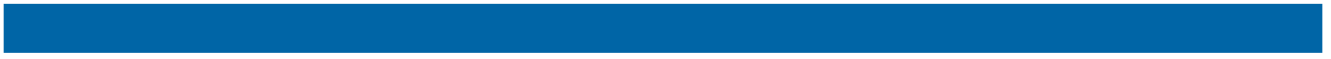

$0 \%$

$10 \%$

$20 \%$

$30 \%$

$40 \%$

$50 \%$
Percentage

$60 \%$

$70 \%$

$80 \%$

$90 \%$

$100 \%$

Fig. 2 Distribution of measles cases by signs and symptoms, Shabwah governorate, February-May 2018 
Table 2 Factors associated with measles outbreak, Shabwah governorate, February-May 2018

\begin{tabular}{|c|c|c|c|c|}
\hline Variables & $\begin{array}{l}\text { Case } \\
\text { No. (\%) } \\
(n=73)\end{array}$ & $\begin{array}{l}\text { Control } \\
\text { No. }(\%) \\
(n=146)\end{array}$ & $\begin{array}{l}\text { Crude OR } \\
(95 \% \mathrm{Cl})\end{array}$ & $\begin{array}{l}\text { Adjusted OR } \\
(95 \% \mathrm{Cl})\end{array}$ \\
\hline \multicolumn{5}{|l|}{ Age group } \\
\hline$<5$ years & $41(56)$ & $51(35)$ & $2.4(1.3-4.2)$ & $1.4(0.2-8.1)$ \\
\hline$\geq 5$ years & $32(44)$ & $95(65)$ & & \\
\hline \multicolumn{5}{|l|}{ Father education } \\
\hline Illiterate - basic & $49(67)$ & $70(48)$ & $2.2(1.2-3.9)$ & $1.3(0.3-5.5)$ \\
\hline Secondary - university & $24(33)$ & $76(52)$ & & \\
\hline \multicolumn{5}{|l|}{ Mother education } \\
\hline Illiterate - basic & $71(97)$ & $129(88)$ & $4.7(1.1-20.8)$ & $8.2(0.4-157.7)$ \\
\hline Secondary - university & $2(3)$ & $17(12)$ & & \\
\hline \multicolumn{5}{|l|}{ Nutritional status $^{a}$} \\
\hline Malnutrition & $9(19)$ & $3(5)$ & $4.8(1.2-18.7)$ & $24.9(1.9-329.6)^{b}$ \\
\hline Normal & $39(81)$ & $62(95)$ & & \\
\hline \multicolumn{5}{|l|}{ Vaccination status } \\
\hline Unvaccinated & $63(86)$ & $35(24)$ & $19.9(9.3-43.1)$ & $17.2(2.9-100.7)^{b}$ \\
\hline Vaccinated & $10(14)$ & $111(76)$ & & \\
\hline \multicolumn{5}{|l|}{ Contact with measles case } \\
\hline Contact & $68(93)$ & $39(27)$ & $37.3(14.0-99.2)$ & $27.3(1.3-551.7)^{b}$ \\
\hline Not contact & $5(7)$ & $107(73)$ & & \\
\hline \multicolumn{5}{|c|}{ Presence of measles case in the same area } \\
\hline Yes & $62(85)$ & $35(24)$ & $17.9(8.5-37.7)$ & $1.1(0.1-19.2)$ \\
\hline No & $11(15)$ & $111(76)$ & & \\
\hline \multicolumn{5}{|l|}{ House ventilation } \\
\hline Bad & $35(48)$ & $21(14)$ & $5.5(2.9-10.5)$ & $1.7(0.4-7.2)$ \\
\hline Good & $38(52)$ & $125(86)$ & & \\
\hline \multicolumn{5}{|c|}{ Distance between home and health facility } \\
\hline$\geq 3.3 \mathrm{~km}$ & $21(29)$ & $57(39)$ & $0.6(0.3-1.2)$ & $3.8(0.6-23.1)$ \\
\hline$<3.3 \mathrm{~km}$ & $52(71)$ & $89(61)$ & & \\
\hline \multicolumn{5}{|l|}{ Crowding (Person per room) } \\
\hline$\geq 2.5$ & $43(59)$ & $65(45)$ & $1.8(1.0-3.2)$ & $0.7(0.2-2.5)$ \\
\hline$<2.5$ & $30(41)$ & $81(55)$ & & \\
\hline \multicolumn{5}{|l|}{ Family size } \\
\hline$\geq 7$ & $61(84)$ & $133(91)$ & $0.5(0.2-1.2)$ & $3(0.4-23)$ \\
\hline$<7$ & $12(16)$ & $13(9)$ & & \\
\hline
\end{tabular}

${ }^{\mathrm{a} N u m b e r}$ of children aged 6-60 months are 113 (48 cases and 65 controls)

${ }^{\mathrm{b}} P$ value $<0.05$

children of illiterate or low educated mothers aren't significantly associated with measles infection. This finding agrees with study in Indonesia and Ethiopia [30,31] and disagrees with study in Ethiopia [32].

Our results revealed that there is a strong association between malnutrition and measles infection. Malnourished children are at risk of measles infection 24 times than normal children. Our finding is consistent with studies in Pakistan and Ethiopia [21, 28] and inconsistent with other study in Ethiopia [32].

Regardless of vaccinated dose number, the results also reflect a strong significant association was observed between vaccination status and measles outbreak, therefore measles vaccine reduced the probability of getting measles infection 17 times during outbreak. This clearly suggests that measles infection is vaccine preventable. Our result agrees with two 
studies in Pakistan [21,33], and others studies; one in Iran [22] and in Indonesia [30] and three in Ethiopia [29, 32, 34].

Additionally, there was found a strong association between the contact with measles cases. The individuals who contact with measles cases have a chance to get measles infection 27 times than those not in contact with the cases. This study result suggests the fact that measles virus has a secondary attack rate among susceptible individuals and the disease transmission by respiratory droplets in close case contacts. The result of this study is similar to previous studies in Pakistan, Southeast Iran, Indonesia and Zimbabwe [21, 22, 30, 35] and five studies in Ethiopia [28, 29, 31, 32, 34].

The current investigation indicates that there isn't significant association between distance of health facility and measles infection. This may be because cases and controls were selected from the same place of residence. The result of this study is inconsistent with a previous two studies in Pakistan [21,33]. We also found that there isn't significant association between crowding and the chances of getting measles infection. This result agrees with studies in Ecuador, Ethiopia and Zimbabwe [20, 34, 35].

The study is a retrospective design in which recall bias might be raised. Use suspected instead of confirmed case definition to identify the cases in the field. Results of our study might not generalize to all governorates of Yemen because it was done in only one governorate.

In conclusion, measles outbreak in Ataq and Habban districts was confirmed. Contact with measles cases was the predominant contributing factor of measles outbreak in Shabwah governorate. As well malnutrition and unvaccination were potential factors that contributed to the occurrence of this outbreak.

An urgent vaccination campaign with health education interventions are highly recommended. Health authorities and the World Health Organization should focus to reactivate the outreach immunization services and strengthen surveillance and response system at district and governorate levels.

\section{Abbreviations}

AR: Attack rate; aOR: Adjusted Odds Ratio; cOR: Crude Odds Ratio;

Cl: Confidence Interval; EMR: East Mediterranean Region; OR: Odds Ratio

\section{Acknowledgements}

We would like to acknowledge and appreciate the Yemen Field Epidemiology Training Program, Eastern Mediterranean Public Health Network, TEPHINET and CDC for their technical support. Also we thank all data collectors; Khaled Barek, Saeed Baker, Ahmad Al Mehthar. We are grateful to Malak Al Sabahi for checking English language of our manuscript.

\section{Authors' contributions}

AAHN was the author involved in the design, implementation of the study, data collection, statistical analysis, wrote the report, drafted the manuscript. MAA was co-author involved in statistical analysis, review the report and the manuscript. FD was co-author involved in the final manuscript revision. MQ was co-author involved in investigation, data collection. All authors read and approved the manuscript.

\section{Funding}

The author(s) received no financial support for the research, authorship, and/ or publication of this article.

\section{Availability of data and materials}

All relevant data are presented in this paper; and more information can be provided upon reasonable request from the correspondence author.

\section{Declarations}

\section{Competing of interests}

The authors declare that they have no competing interests.

\section{Ethics approval and consent to participate}

This study was part of an outbreak response, an official approval was obtained from the Ministry of Public Health Population of Yemen and an official letter was sent to Shabwah Governorate Health Office to conduct this investigation by the Field Epidemiological Training Program. The consent was obtained from all participants. The participants were less than 18 years, the consent was obtained from their parents. Confidentiality of data was assured and ensured.

\section{Consent for publication}

Not applicable.

\section{Author details}

'Sana'a City's Public Health and Population Office, Yemen Ministry of Public Health and Population, Sana'a, Yemen. ${ }^{2}$ Field Epidemiology Training Program, Yemen Ministry of Public Health and Population, Sana'a, Yemen. ${ }^{3}$ Evaluation and Monitor Department, World Health Organization- Yemen, Sana'a, Yemen. ${ }^{4}$ Heidelberg Institute of Global Health, Medical School , Heidelberg University, 69120 Heidelberg, Germany. ${ }^{5}$ IRIA, Akkon-Hochschule fuer Humanwissenschaften, 12099 Berlin, Germany.

Received: 7 November 2020 Accepted: 18 May 2021

Published online: 10 June 2021

\section{References}

1. Nsubuga F, Bulage L, Ampeire I, Matovu J, Kasasa S, Tanifum P, et al. Factors contributing to measles transmission during an outbreak in Kamwenge District, Western Uganda, April to august 2015. BMC Infect Dis. 2018;18(21):1-7.

2. Vaidya SR, Kamble MB, Chowdhury DT, Kumbhar NS. Measles \& rubella outbreaks in Maharashtra state, India. Indian J Med Res. 2016;143(2):227-31. https://doi.org/10.4103/0971-5916.180214.

3. Nanben OV, Emmanuel M, Onyemocho A, Julius G, Elisha P. A Retrospective Investigation of a Measles Outbreak in a District in North-western Nigeria. Public Health Int. 2017;2(3):96-101. https://doi.org/10.11648/j.wjph.20170203.12.

4. WHO. Newsroom. Facts in pictures. Detail. Measles. 15/3/2018:1-3. http://www. who.int/news-room/facts-in-pictures/detail/measles. Accessed 13 June 2018.

5. Centers for Disease Control and Prevention. Parasites. Global Health. 2017 Annual Report. Available at: https:/www.cdc.gov/globalhealth/resources/ reports/annual/2017/global-immunization-division-gid.html. Accessed 9 Feb 2019.

6. WHO, EMRO. Vaccine preventable diseases, Measles and rubella surveillance summary and data analysis of selected performance indicators. Measles and Rubella Monthly bulletin. Week 53 2016: Available at: http://www.emro.who. int/images/stories/vpi/documents/measles_rubella_2016.pdf?ua=1. Accessed 3 Mar 2019

7. Qirbi N, Ismail S. Ongoing threat of a large-scale measles outbreak in Yemen. Lancet Glob Health. 2016;4(7):e451. https//doi.org/10.1016/52214-109X(16)30070-5.

8. MoPHP. EPI. Information and Statistical Department. Children Immunization Coverage 2017

9. MoPHP. Measles Surveillance Program, Measles Data 2017.

10. MoPHP. Measles Surveillance Program, Measles Data 2018.

11. Alnajjar MA. Measles outbreak investigation in Qufl Shamr, Hajja governorate, Yemen, 2012. First national Y-FETP conference. 26-27 Feb 2014 71. Download from: http://www.yfetp.com/OPSHandler/Resources/Atta chment/RoxyFileman//First\%20National\%20YFETP\%20Conference\%2 0Book\%20Feb\%202014.pdf

12. Al Amad MA, and Qaseem M. Measles outbreak at Al Zeliah Village, Al Hudaydah governorate, Yemen, November 2014. 2nd Y-FETP National 
Conference. 29 Feb 2016:50. Download from: http://www.yfetp.com/imgs/2 nd\%20Y-FETP\%National\%Conference\%Book\%2029\%20Feb\%202016\%20_3.pdf.

13. Bashamakha G, and Al Amad M. Measles Outbreak at Al Jawf Governorate, Yemen, March, 2015. 2nd Y-FETP National Conference. 29 Feb 2016:48. Available at: http://www.yfetp.com/imgs/2nd\%20Y-FETP\%National\% Conference\%Book\%2029\%20Feb\%202016\%20_3.pdf.

14. Dehnan M, and Al Abhar N. Measles Outbreak in Sa'adah Governorate, Yemen, 6th - 10th of March 2015. 2nd Y-FETP National Conference. 29 Feb 2016:51. Available at: http://www.yfetp.com/imgs/2nd\%20Y-FETP\%National\% Conference\%Book\%2029\%20Feb\%202016\%20_3.pdf.

15. Mayad M, Albakhshi W. Measles Outbreak-Khywan, Huth District, Amran Governorate, Yemen, March, 2017. iproc. 2018;4(1):e10591. https://doi.org/1 0.2196/10591.

16. Berghof Foundation. Library. Mapping of Local Governance in Yemeni Governorates. Berlin: Berghof Foundation; 2020. Available at: https:// berghof-foundation.org/library/mapping-of-local-governance-in-yemenigovernorates

17. MoPHP. eDEWS Program, Measles Data January-May 2018.

18. Shamsan F. Measles Outbreak Report in Sa'adah Governorate, Yemen, 2012. 1st Y-FETP National Conference. 26-27 February 2014:36. Available at: http://www. youblisher.com/p/1465957-First-National-YFETP-Conference-Book-Feb-2014-1/.

19. Belda K, Tegegne AA, Mersha AM, Bayenessagne MG, Hussein I, Bezabeh B. Measles outbreak investigation in Guji zone of Oromia Region, Ethiopia. Pan Afr Med J. 2017; 27(Suppl 2):9. https:/doi.org/10.11604/pamj.supp.2017.27.2.10705.

20. Rivadeneira MF, Bassanesi SL, Fuchs SC. Role of health determinants in a measles outbreak in Ecuador: a case-control study with aggregated data. BMC Public Health. 2018;18(1):269. https://doi.org/10.1186/s12889-018-5163-9.

21. Bullo MM, Baig MA, Malik JF, Khan EA, Ranjha MA. I. aSS. Measles outbreak in a rural area of a developing country: a case control study. Pakistan J Public Health. 2017;7(4):197-201.

22. Izadi S, Zahraie SM, Sartipi M. An investigation into a measles outbreak in Southeast Iran. Jpn J Infect Dis. 2012;65(1):45-51.

23. WHO, and UNICEF. WHO child growth standards and the identification of severe acute malnutrition in infants and children; 2009. p. 1-12. Available at: http://apps.who.int/iris/bitstream/handle/10665/44129/9789? sequence=1

24. MOPHP. Yemen National Health and Demographic Survey, vol. 16; 2013. Available at: https://dhsprogram.com/pubs/pdf/FR296/FR296.pdf

25. Karki KB. Measles outbreak in Kapilvastu, Nepal: an outbreak investigation. Nepal Health Res Council. 2016:1-30 Available at: http//librany.nhrc.gov.np:8080/nhrc/bitstream/ha ndle/123456789/793/Measles\%200utbreak\%20Investigation.pdf?sequence $=1$.

26. MoPHP, Shabwah Governorate's PHP Office, Immunization department. Immunization Coverage Data. 2017 and 2018.

27. Woyessa AB, Said AA. Measles outbreak investigation - Keffa zone, SNNP regional state, Ethiopia, January 2012. Int J Infect Dis. 2012;16:e365. https:// doi.org/10.1016/j.jiji.2012.05.461.

28. Ayele WM. Malnutrition Precipitated Measles Outbreak in Gewane District, Afar Regional State, Northeastern Ethiopia, 2016. Research Square; 2020. doi: https://doi.org/10.21203/rs.3.rs-32423/v1.

29. Ismail AS, Aden MA, Abdikarim AA, Yusuf AA. Risk Factors for Measles Outbreak: An Unmatched Case Control Study in Kabridahar District, Somali Regional State, Ethiopia. Am J Epidemiol Infect Dis. 2019;7(1):1-5. https:// doi.org/10.12691/ajeid-7-1-1.

30. Sitepu FY, Depari E, Mudatsir M, Harapan H. Being unvaccinated and contact with measles cases as the risk factors of measles outbreak, North Sumatera, Indonesia. Clin Epidemiol Global Health. 2020;8(1):239-43.

31. Tariku MK, Misikir SW. Measles outbreak investigation in Artuma Fursi Woreda, Oromia zone, Amhara region, Ethiopia, 2018: a case control study. BMC Res Notes. 2019;12(1):1-6. https://doi.org/10.1186/s13104-019-4806-y.

32. Kalil FS, Gemeda DH, Bedaso MH, Wario SK. Measles outbreak investigation in Ginnir district of Bale zone, Oromia region, Southeast Ethiopia, May 2019. Pan Afr Med J. 2020;36:20. Published 2020 May 14. https//doi.org/10.11604/pamj.2020.36.20.21169.

33. Ismail M, Khan A. Measles Outbreak Investigation in Village Bara, Khyber Agency, Pakistan-February 2017: Case Control Study. iproc. 2018;4(1):e10593. https://doi.org/10.2196/10593.

34. Girmay A, Dadi AF. Being unvaccinated and having a contact history increased the risk of measles infection during an outbreak: a finding from measles outbreak investigation in rural district of Ethiopia, 2016. BMC Infect Dis. 2019;19(1):345. https://doi.org/10.1186/s12879-019-3973-8.

35. Pomerai KW, Mudyiradima RF, Gombe NT. Measles outbreak investigation in Zaka, Masvingo Province, Zimbabwe, 2010. BMC Res Notes. 2012;5(1):687. https://doi.org/10.1186/1756-0500-5-687.

\section{Publisher's Note}

Springer Nature remains neutral with regard to jurisdictional claims in published maps and institutional affiliations.
Ready to submit your research? Choose BMC and benefit from:

- fast, convenient online submission

- thorough peer review by experienced researchers in your field

- rapid publication on acceptance

- support for research data, including large and complex data types

- gold Open Access which fosters wider collaboration and increased citations

- maximum visibility for your research: over $100 \mathrm{M}$ website views per year

At $\mathrm{BMC}$, research is always in progress.

Learn more biomedcentral.com/submissions 